\title{
EFFECTS OF FOREST FIRES ON THE ECONOMY OF THE SUNGAI WAIN PROTECTED FOREST ECOSYSTEM, EAST KALIMANTAN, INDONESIA
}

\author{
Dai Ambo, Aipassa Marlon I., Kustiawan Wawan, Karyati, Ruslim Yosep \\ Faculty of Forestry, University of Mulawarman, Samarinda, East Kalimantan, Indonesia \\ *E-mail: yruslim@gmail.com
}

\begin{abstract}
The problem of fire is that most people carry out burning activities on the grounds that burning costs are cheaper than using tree or grass cutting tools, fires are carried out without good preparation, so that people who burn are often not familiar with fire-fighting techniques, so any incident can occur. In order to provide education to the community and government, the authors conducted a study on the location of Sungai Wain Protected Forest (HLSW), with a total area of 11,245 hectares. Inside there are two rivers, namely the Wain River and the Bugis River. Both rivers are under pressure from ecosystem damage, stemming from forest fires, which have an impact on decreasing the ecological function of land and rivers. To determine the HLSW management policy, in order to reduce the potential for forest fires, the researcher used the Vensim dynamic system, the goal was to obtain an analysis of the effects of fire on water availability in HLSW. Utilization of forest ecosystem products in the form of water availability for human use for drinking water, bathing and other activities. The water needs of the community around HLSW per year is $250,419.24 \mathrm{m3}$. Water needs of PT. Pertamina per year is 5,256,000 m3, the need for water for firefighting per year is $5,540 \mathrm{~m} 3$. The availability of water in HLSW is strongly influenced by the level of rainfall, the amount of land area, vegetation in HLSW and the impact of forest fires and other damage.
\end{abstract}

\section{KEY WORDS}

Extinct plants, forest ecosystems, forest fires.

The recurrence of fire cases in Indonesia from year to year shows that fire management efforts in Indonesia are still inadequate. This is known from various information about the incidence of fires every year in various regions in Indonesia. This shows that there are still many unresolved problems. Lack of synergy between all elements of society or institutions, both government and private, has resulted in a lack of concern from various parties regarding the dangers of fire so that the institutionalization of prevention efforts still faces various problems. Fire is more of a disaster as a natural disaster so most parties do not regulate fire planning. In the context of tackling forest and land fires, humans can only do two things, namely preventing and extinguishing fires early. Forest community engagement systems that can act as both triggers and deterrents have improved rapidly in some areas. Forest fires and natural disasters are currently natural disasters, National Disaster Management Authority (BNPB, 2013).

Forest fires are one of the causes of breaking the chain of ecological systems in forests. Forests are ecosystems that have a very large function in the survival of humans and other living things. In the city of Balikpapan there is a tropical rain forest ecosystem, in which there is a diversity of species that are formed in tropical climates with high rainfall and low humidity. Forest fires are considered an organized crime, which is one of the factors that cause forest fires to be man-made. Ninety percent of forest fires are caused by elements of human intention aimed at clearing plantation land (Purnomo, 2015).

One of the pressures of HLSW is that forest fires occur every year and this also occurs in several other provinces in Indonesia. In the last HLSW condition, of the area of 9,783 hectares only $39 \%$ remained as natural forest or an area of 3,841 hectares, while $41.6 \%$ were damaged due to forest fires in 1998 or an area of 4,071 hectares. and around $17.4 \%$ have changed their function due to encroachment (land tenure). or an area of 1,703 hectares. This condition tends to continue to change because until now there is still land use 
in the area by the surrounding community which is considered to be less controlled, especially through activities of clearing arable land, logging timber, collecting non-timber forest products and so on. All of these activities have an economic motive (Rujehan, 2010).

In the Amazon forest, the effects of forest conversion from fire or cropland indicate severe changes in the hydrological cycle such as variability of groundwater storage and the ability to extract water from soil depth (Hodnett et al. 1995; Grip et al. 2004). In tropical forests, the effects of forest conversion by fire or for agricultural purposes have resulted in severe changes in the hydrological cycle, with changes in groundwater retention and the ability to extract water from soil depth (Brown et al. 2013; Turetsky et al. 2015). Hydrological change as a result of forest conversion is the change in the amount of water that is intercepted and evaporated into the atmosphere from the surface of vegetation (Dietz et al. 2006). Capture and distribution of water in a forest are influenced by tree structure and vegetation stands such as vertical and horizontal leaf arrangement, leaf morphology, branching, tree age, and density (Levia and Frost 2006; Holder 2007). Stem density, tree height, and crown properties (ie leaf area index, crown cover, crown surface area and epiphytes) can change water flow (Levia \& Frost 2006). Other results suggest that differences between tree species have a significant impact on the quantity of rainfall shared through stem flow; Smooth-skinned tree species provide more rainfall as trunk flow to the forest floor than coarse-skinned species (Astiani et al. 2017).

The last condition of Sungai Wain Protected Forest, from the previous area in 1995 which was 9,500 hectares, increased to 11,245 hectares, according to the Decree of the Minister of Forestry No. 3922 concerning the Designation of Sungai Wain Protection Forest to 11,245 hectares. An additional 1,463 hectares (13\%) is located to the west of the HLSW area. Of this area, $41.6 \%$ were damaged by forest fires in 1998 or an area of $4,677.92$ hectares and around $17.4 \%$ have changed their function due to encroachment (land control) or an area of 1,703 hectares. The incidence of forest and land fires inside and outside the Sungai Wain Protected Forest in 2014, the total area burned was 165.6 hectares, in 2015, the area of land burned was 911.45 hectares, in 2016, the area of land burned was 45, 55 hectares, in 2017, 17 hectares of land burned, in 2018, the area of land burned was 10.5 hectares, and in 2019, the area burned was 256.31 hectares. This figure gives an indication to the government, community and business world that there needs to be great attention from all parties to control forest fires, both inside and outside HLSW.

There are several watersheds (DAS) within the Wain River protected forest, namely the Bugis river basin and the Wain River watershed. Postel and Thompson (2005) state that a watershed is an area of land that flows into a common water source. Watersheds connect and encompass terrestrial, freshwater, and coastal ecosystems, they perform a wide variety of valuable services, including the provision and purification of fresh water, provision of habitats that protect fisheries and biodiversity, and others. Watershed functions are very complex and influenced by several factors, namely vegetation, topography, soil and settlement (Triwanto 2012). Furthermore, Triwanto (2012) states that a change in one of the factors will affect the watershed ecosystem and can reduce the function of the watershed. Vegetation is a unit of plants that live side by side in an area that interacts with each other and with their environment (Mueller-Dumbois and Ellenberg 1974; Susanto 2012).

Parejiya et al. (2013) stated that the vegetation of a region is a function of several factors such as time, altitude, slope, latitude, aspect, rainfall. The variation in species diversity along environmental gradients is a major topic of ecological investigation and has been described with reference to climate, productivity, biotic interactions, habitat heterogeneity, and history. Zheng et al. (2007) add that the vegetation canopy can intercept the raindrops falling on it, hold it above the canopy and then release it to the ground or allow it to flow through the trunk, thereby reducing its kinetic energy when it falls to the ground. The role of vegetation for water and soil conservation is largely determined by its structure and composition. The vegetation structure according to Arrijani (2006) is an organization in space where individuals form a stand or an extension of the type of stand that forms an association as a whole. Environmental factors include soil temperature, $\mathrm{pH}$, and nutrient content in the soil. In addition, Krebs (2009) and Ardhana (2012) state that climatic conditions in plant 
habitats also affect plant communities. Altitude is one of the environmental factors. The height of some areas affects the value of importance index (IVI) of vegetation.

Watershed is an integrated ecosystem, from upstream to downstream consisting of land, plants, water and air as the main elements, and has an important role in sustainability. community economic development in. The watershed is currently one of the natural ecosystems that are prioritized for protection. Watershed ecosystem protection which is currently increasingly critical is considered very important because it plays a role in many environmental services that are vital to human life (Zhang et al. 2011; Daye and Healey 2015). The carrying capacity of forest areas in the watershed has decreased, as reflected in frequent flooding, drought, landslides and an increase in critical land, including conservation forest (Paimin et al. 2012). According to data from the Food and Agriculture Organization (FAO), about a third of major cities in the world, such as Bogota, Tokyo, Barcelona and New York, rely heavily on protected forests to provide drinking water for around 238 million people in these cities (Profauna, 2016).

\section{MATERIALS AND METHODS OF RESEARCH}

The research was conducted in the Sungai Wain Protected Forest (HLSW) area which was stipulated by the Decree of the Minister of Forestry No. 3922 concerning the Designation of Sungai Wain Protected Forest, covering 11,245 hectares. Ingeographicallocated at $116^{\circ} 47^{\prime}$ $116^{\circ} 55^{\prime}$ East Longitude and $01^{\circ} 02$ '- $01^{\circ} 10^{\prime}$ South Latitude.Parts of the research area are the northern part bordering the administrative area of Kutai Kartanegara Regency, the western part bordering the land belonging to PT. Inhutani, the southern part is bordered by the Kariangau Industrial Area, and the eastern part is bordered by the community forest area in North Balikpapan, Figure 1. The research was conducted from February 2019 to February 2020.
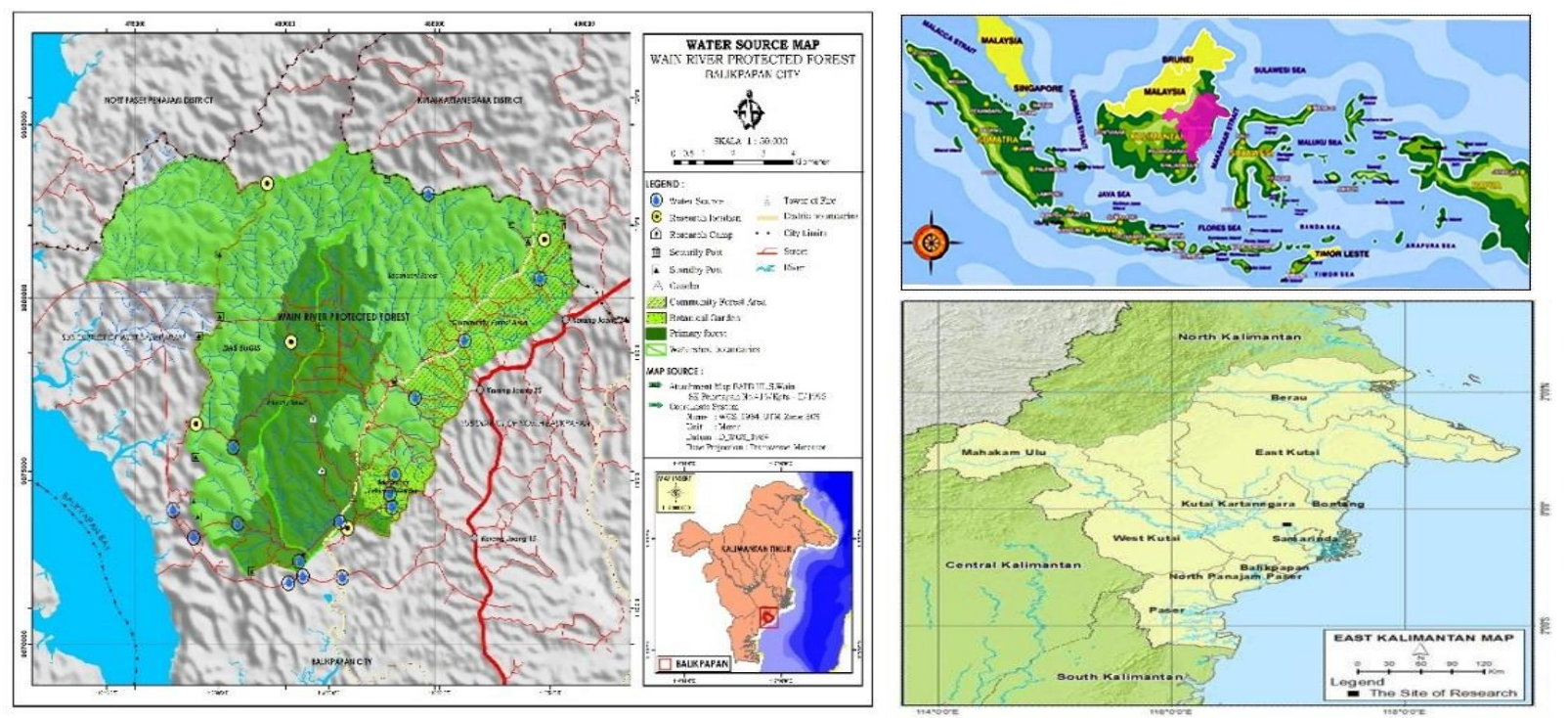

Figure 1 - Location study of Sungai Wain Protection Forest (HLSW) Data analysis

Climatic element analysis (monthly rainfall, temperature monthly maximum air, and average air temperature monthly) differentiated based on the model fit test regression, namely regression analysis to analyze the relationship between climate elements and the appearance of hotspots (hotspot) and Pearson correlation analysis. The climate element data is used as the independent variable and the fire incident data is used as the response variable. Correlation analysis is used to find out the relationship between two or more data variables quantitative in nature (Walpole 1982). In this research, correlation analysis (R) between climatic elements (monthly rainfall, and maximum monthly air temperature) and climatic elements observations of the Meteorology, Climatology and Geophysics Agency. 
Secondary data which became the model variables included the area of protected forest land in the Wain river, the area of community forest land, and the area of the Balikpapan Botanical Garden. The average level of rainfall and temperature and temperature are the primary data measured at the research location. Another variable is the use of PT. Pertamina, the use of community water around HLSW and use of firefighting water. The leverage variable is the fire effect that results from the strong correlation between rainfall and fire incidence. Furthermore, these variables are included in the structure of the water availability model.

The variables that have been measured as scientific data using the Automated Weather System (AWS) at each location. Location one with an average temperature value of $31.1^{\circ} \mathrm{C}$, an average humidity of $69.4 \%$, wind speed of $2.1 \mathrm{kw} /$ hour, rain $110.8 \mathrm{~mm} /$ day, location two with an average temperature value of $30,4^{\circ} \mathrm{C}$, average humidity $67.6 \%$, wind speed $12.5 \mathrm{kw} /$ hour, rain

$15.3 \mathrm{~mm} /$ day, location three with an average temperature value of $29.0^{\circ} \mathrm{C}$, average humidity $81,7 \%$, wind speed $10.0 \mathrm{kw} /$ hour, rain $122 \mathrm{~mm} /$ day, location four with an average temperature value of $30.0^{\circ} \mathrm{C}$, average humidity $71.6 \%$, wind speed $12.9 \mathrm{kw} /$ hour, rain 0.4 $\mathrm{mm} /$ day and five locations with an average temperature value of $30.1^{\circ} \mathrm{C}$, an average humidity of $85.2 \%$, a wind speed of $2.8 \mathrm{kw} /$ hour, $103.5 \mathrm{~mm} /$ day of rain.

According to (Muhammadi, 2001), dynamics system modeling can be done in several stages, namely:

- Concept creation. The initial stage is to identify the problem, find out who is handling it and why it happened. Then each event is studied to find a pattern. From this pattern, problems can be formulated and are called mental models. The resulting mental model is described in a diagrammatic model called a causal loop diagram (CLD). CLD is a disclosure about the occurrence of a cause and effect relationship into a certain image language. The arrows that represent the relationship, intertwine to form a causal loop, where the arrowheads reveal the cause and the arrowheads reveal the effect;

- Model making. After the CLD is formed, then a computer model is built called a stockflow diagram (SFD). SFD is translated more broadly using computer symbols in accordance with the selected software, namely Vensim. These symbols include symbols that describe stock (level), flow (rate), auxiliary, and constants;

- Data input. To analyze a model, data obtained from field observations, both primary and secondary data, are input into the SFD. The method of entering data into the model is highly dependent on the type of data. Data can be entered into the model as stock, as flow, as auxiliary, and also as constant;

- Model Simulation. Based on SFD which already contains data, simulation is carried out to get the results. Before the simulation is carried out, the simulation specifications are first determined which include the simulation time range, the integration method, and the time step. Simulation is a dynamic process of model behavior, the output of which is a time behavior graph and a time table;

- Model validation. Model verification is done to check the suitability of the model that has been made with the applicable principles and also to evaluate some sources of errors that often occur in modeling. Meanwhile, validation is the last stage in modeling to check the model by reviewing whether the model output is in accordance with the real system or not. In other words, it is said to be valid if it displays things that match reality.

\section{RESULTS AND DISCUSSION}

Dynamic Model of HLSW Fire Control Analysis. There are several approaches in policy and decision analysis, including a dynamic systems approach to formulate, simulate and validate data by looking at system behavior in the future. With this scenario process, it is hoped that the function of the Sungai Wain Protection Forest (HLSW) ecosystem will function properly, in order to maintain the stability of the forest and watershed ecosystems. 
The simulation process is expected to provide answers to the parameters that affect the stability of ecosystem functions. It is hoped that the results of future scenario simulations can provide a real picture to the community, government and the business world, that the role of the HLSW ecosystem has a major influence on the economic, social and environmental behavior of the HLSW ecosystem itself.

This method was developed in Portugal, managing forest fires, developing systems insight through social and physical dynamics models (Collins, 2012). Analysis of fire control models using the Vensim program dynamic system, aims to see the level of fire influence on the behavior of water availability in the HLSW ecosystem. The results of the model analysis will provide a behavioral pattern of water availability in HLSW so that it will provide an overview of the effects of fire and the level of water availability in the future. Several indices or codes are used as parameters for fire hazard ratings in the model, namely: FFMC (Fine Fuel Moisture Code), DMC (Duff Moisture Code), DC (Drought code), and FWI (Fire Weather Index), ISI (Initial Spread Index).

Protected forest of the Wain River with an area of 11,425 hectares, in which there are the Wain River Basin and the Bugis Watershed. There are sixteen surface water sources in HLSW, can be seen in Figure 2.

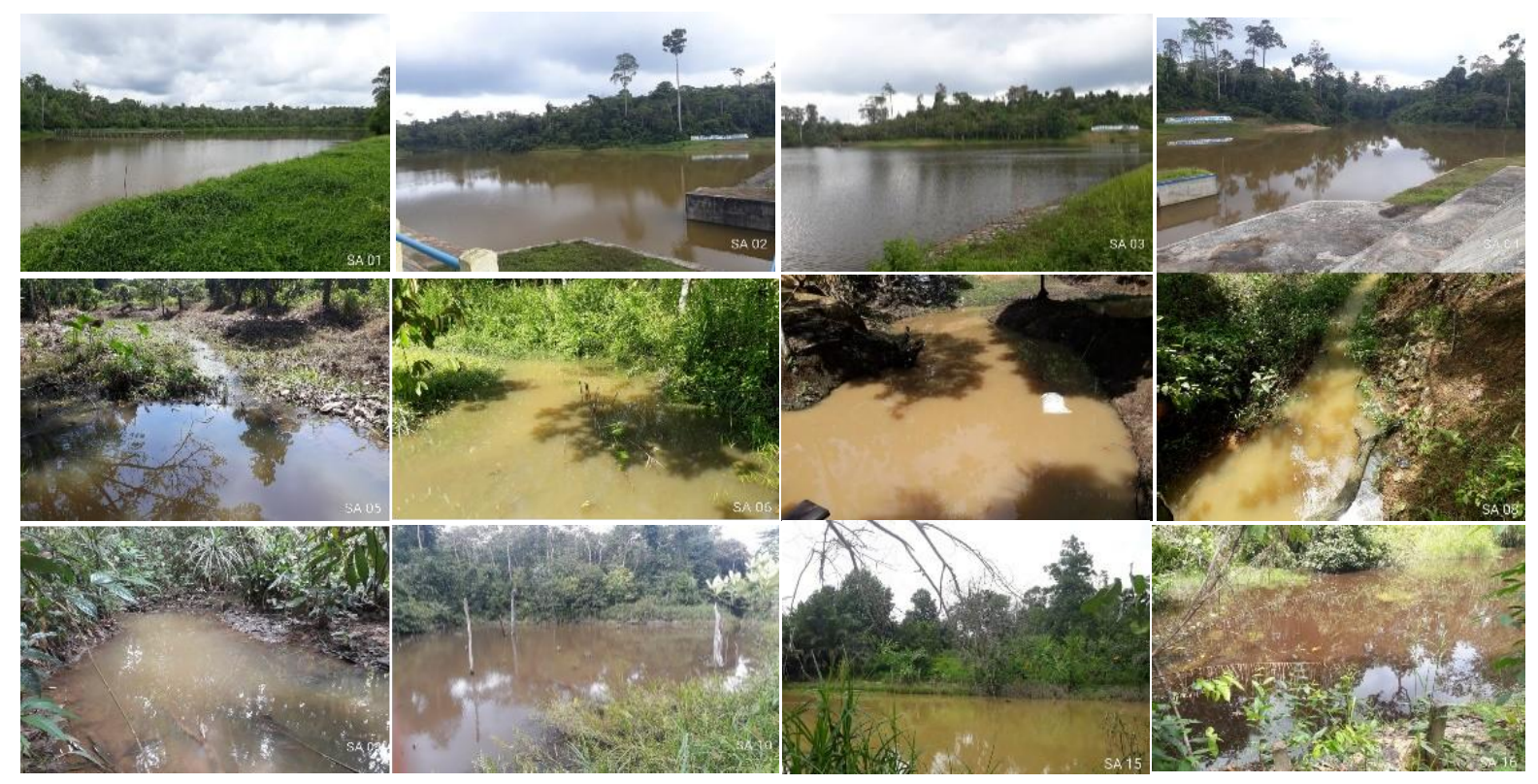

Figure 2 - Surface Water Sources in HLSW

The threat of damage to the Sungai Wain protected forest comes from humans who expand plantation activities, housing development activities, bordering the East Kalimantan Institute and designating Penajam and Kutai Kartanegara Regencies as the capitals of the Unitary State of the Republic of Indonesia, both cities are directly adjacent to Balikpapan City, Forest The Wain River Protection is in this city. All of which will affect changes in the landscape and changes in the economic, social and environmental structures of the community (Rujehan, 2010).

The model structure used is a model structure of water availability in the Sungai Wain protected forest. There are several variables, both secondary data sources and primary field data. The role of HLSW land area and the role of vegetation and also the impact after the fire. This will be carried out by modeling the Vensim program dynamics system. According to Marsono (2008), vegetation has an important role because it functions as a hydrological regulation, flood control, and drought mitigation. Wang et al. (2013) stated that forests play an important role in controlling surface flow through their influence on hydrological processes such as precipitation, interception, and evapotranspiration, affecting soil properties, and changing the amount of rainwater that will enter the soil through infiltration. In addition, Zheng et al. (2007) add that the vegetation canopy can intercept the raindrops falling on it, 
hold it above the canopy and then release it to the ground or allow it to flow through the trunk, thereby reducing its kinetic energy when it falls to the ground.

Vegetation cover is an important factor in influencing erosion (Yan et al. 2011). Increased vegetation cover can increase the build-up of litter on the soil surface to control soil erosion by a maximum of $75 \%$. The vegetation root system can significantly improve soil stability and act as an anti-erosion agent (Zheng et al. 2007).

The role of vegetation for water and soil conservation is largely determined by its structure and composition. The vegetation structure according to Arrijani (2006) is an organization in space where individuals form a stand or an extension of the type of stand that forms an association as a whole. The structure and composition of vegetation in an area are influenced by interacting ecosystem components, so that the vegetation that grows naturally in the area is the result of interactions between environmental factors and can change due to anthropogenic influences. Monitoring of vegetation structure and composition in the Bugis and Wain watersheds.

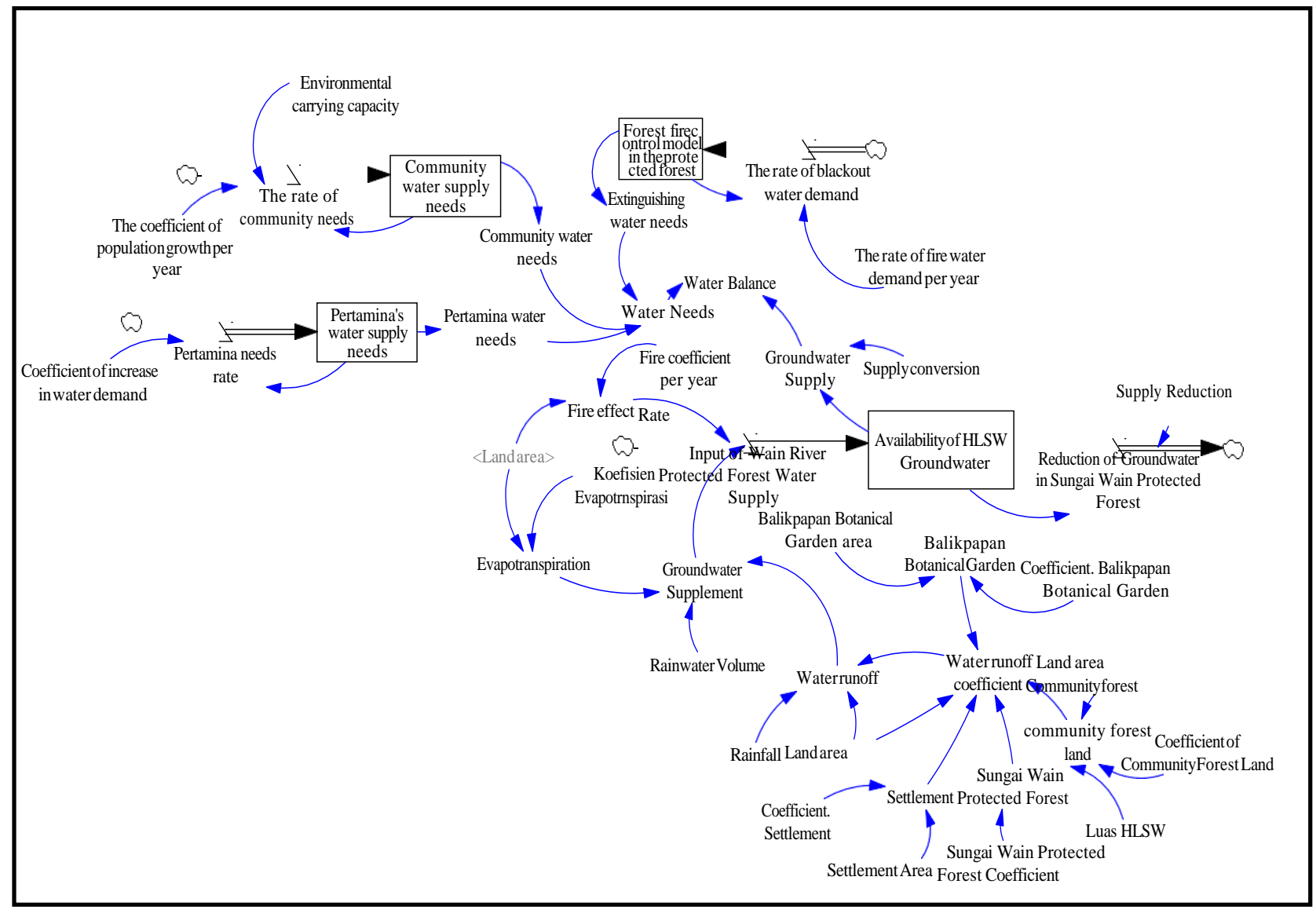

Figure 3 - Structure model of water availability level in Wain river protection forest

Forest damage caused by forest fires greatly affects the discharge of water that will enter the Wain River and Sungai Reservoir Bugis. The destruction of conservation and protection forests, which are generally in the upstream part of the watershed, has disrupted the hydrological cycle (de Paula et al. 2015). Land use change is an effort to increase the economic value of land through the production of estate crops, agriculture or housing, but on the other hand, it actually reduces ecosystem services and biodiversity (Lawler et al. 2014). In the protected forest of the Wain River, there are primary and secondary forests. Both have a different amount of species diversity. The highest number of plant species is found in secondary forest compared to primary forest. Secondary mixed forest generally has a higher diversity of plant species than primary forest (Odum 1998).

To obtain lever variables in the system dynamic model structure, the factors that have 
a strong influence on fire incidence are from several index variables FFMC, DC and FWI. The result of simple linear regression correlation shows the value / relationship (R) of 0.978 and measures the percentage of influence of the independent variable on the variable called determination which is the result of squaring $R$. From this output, the coefficient of determination (R2) is 0.957 , which implies that the effect of independent variable (FWI) on the dependent variable (Fire Area) is $95.7 \%$, while the rest are other factors in variable $X$.

Output section (ANOVA): In this section to explain whether there is a significant (significant) effect of the FWI variable (X) on the Fire Area variable (Y). From this output, it can be seen that $F$ count $=44.062$ with a significance level / probability of $0.022<0.05$, so the regression model can be used to predict the variable of fire area.

A scenario simulation without the effects of fire and other damage to the Sungai Wain Protected Forest ecosystem. Initial water requirements for PT. Pertamina with an initial volume of 5,256,000 m3 per year, with an annual demand scenario of 5 percent, can be seen in Figure 4, the rate of increase each year increases.

The number of requests for water needs from PT. Pertamina in year 10 is $8,560,000$ $\mathrm{m}^{3}$. The value of water needs each year can be seen in Table 1.

Table 1 - Water needs of PT. Pertamina

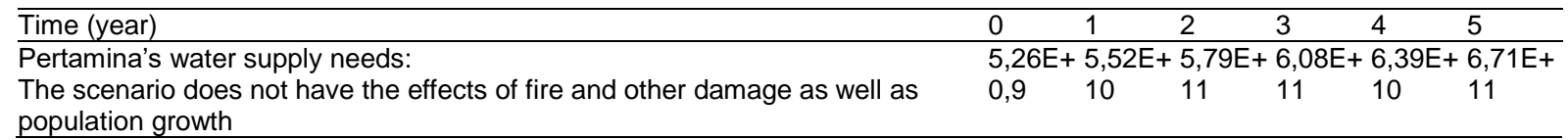

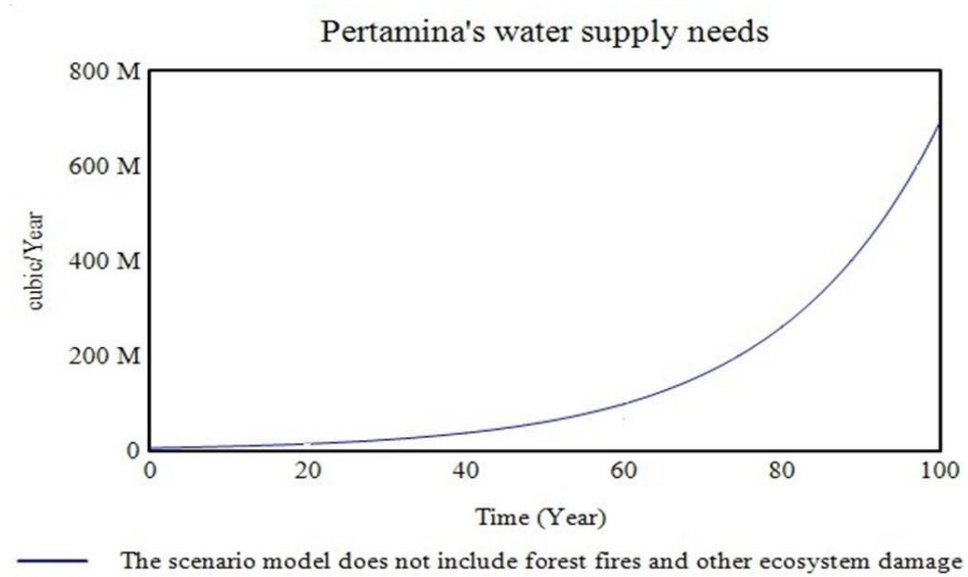

Figure 4 - Pertamina's Drinking Water Demand

Water needs for the company PT. Pertamina is increasing every year, this is influenced by the development of oil processing needs carried out by the company, and from last year until now Pertamina's water needs have increased due to the expansion of Pertamina's oil refineries. This graph increases because demand is influenced by the increase in the coefficient of increasing water demand. Be careful about the water supply to the company, because the water in HLSW is water that is naturally processed, starting from rain that falls to the mainland of the HLSW ecosystem, then is stored in the leaves, roots, then slowly disposed of to the storage area or reservoir through the Wain river basin and the Bugis River. Based on the simulation results show that there is a time of water shortage, so that good water supply management to the company is needed.

The company PT. Pertamina has saved operational costs for water needs; using HLSW water has saved costs compared to producing groundwater which requires a large amount of water purification costs. A survey in the United States showed that the cost of treating water in an area where a watershed (DAS) still has $60 \%$ forest cover is half the cost of treating water in an area with only $30 \%$ forest cover. It is estimated that every US \$ 1 spent on forest and watershed protection would save as much as US $\$ 7.50$ to US $\$ 200$ in water treatment costs, (Profauna, 2016). 
Simulation of a scenario without the influence of fire and other damage to the Sungai Wain Protected Forest ecosystem for initial water requirements for firefighting with an initial volume of $5,549.2 \mathrm{~m}^{3}$ per year, with a scenario of 5 percent water demand per year, it can be seen in graph 6 , the rate of increase each year increases.

The need for fire extinguishing water is influenced by the growth rate of humans and buildings that are standing, these two parameters are very possible for fires, so that the higher the human growth, the higher the need for building housing facilities that have the potential to cause fires.

The total water requirement for firefighters in year 10 is $9,039.06 \mathrm{~m}^{3}$. The value of water requirements can be seen in Table 2 .

Table 2 - Firefighting requirements

\begin{tabular}{|c|c|c|c|c|c|c|}
\hline Time (year) & 0 & 1 & 2 & 3 & 4 & 5 \\
\hline Forest fire control model in the protected forest: & 5549.02. & 5826. & 6117 & 6423 & 6745.09. & 7082.34. \\
\hline $\begin{array}{l}\text { The scenario does not have the effects of fire and other damage as } \\
\text { well as population }\end{array}$ & 00 & 66 & 99 & 89 & 00 & 00 \\
\hline
\end{tabular}

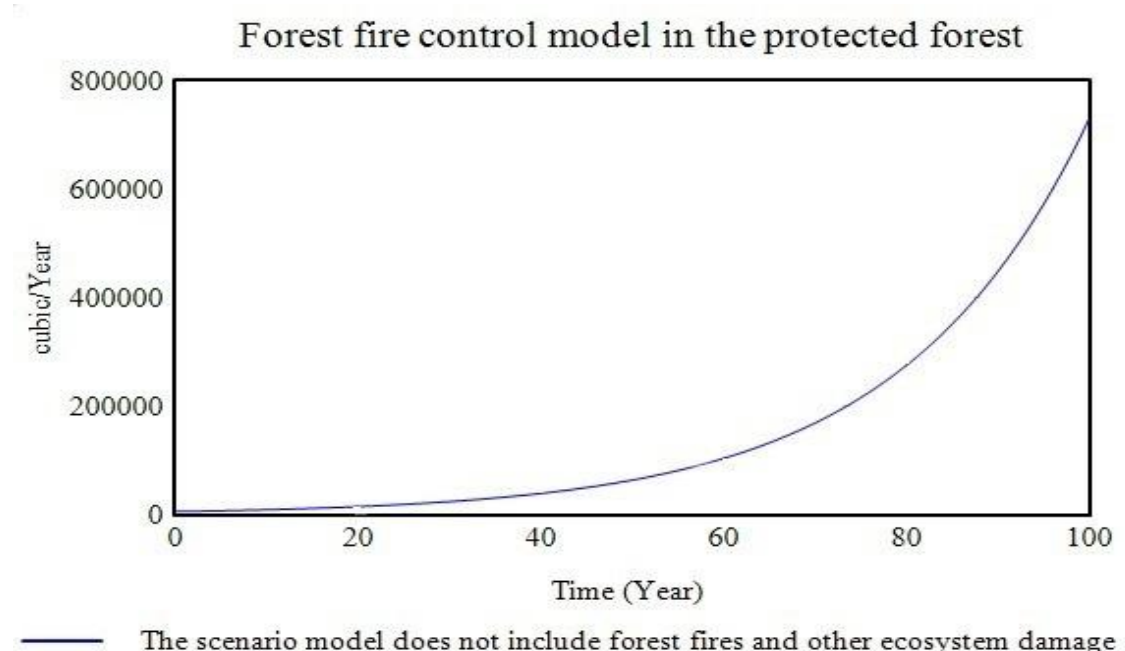

Figure $5-$ Graph of firefighting requirements

The growth of water demand for firefighting services increases every year, the graph from the bottom up over time, this graph is influenced by the development of water demand for each fire extinguisher, and the growth in water demand is directly proportional to the human growth rate, because humans need security, both safe for himself and safe for his assets.

A scenario simulation without the effects of fire and other damage to the Sungai Wain Protected Forest ecosystem for the initial water needs of the community around the Sungai Wain Protection Forest with a volume of $7,000 \mathrm{~m} 3$ per year, a 5 percent annual demand scenario, limited by the environmental carrying capacity of 65,000 people. Fire and other ecosystem damage, with an environmental damage factor of 20 percent. This figure does not exceed the maximum environmental carrying capacity. If it passes the carrying capacity of the environment, then the effect is very large, including the emergence of slum building density, so that environmental sanitation decreases, it can be seen in Figure 6, when it reaches the maximum environmental carrying capacity the need that can be served is the maximum amount of environmental carrying capacity.

The amount of water needs of the community around the Sungai Wain Protection Forest, the need for water increases every year, the model behavior is influenced by the growth rate of the community around 5 percent around HLSW, the peak water demand is $10,700.2 \mathrm{~m}^{3}$ in the 10 th year. The amount of water demand can be seen in Table 3.

The future will have a major influence on the increasing demand for water and demand for forest products. The increase in population affects forest areas because of the need for 
land to meet food and housing needs. The conversion of forest areas to agricultural land, human settlements, and other land uses has a negative impact on land and water resources (Fauzi et al. 2018). However, land use is also closely related to human activities that can disrupt the balance of the ecosystem. The conversion of forest areas to agricultural land also causes damage to ecosystems at the watershed level because most of the areas in the landscape are not suitable for their capacity, affecting their carrying capacity and quality (Sinukaban 2007; Harjianto et al. 2016). Ramadhan et al. (2016) reported that a mismatch in terms of the use of an area can cause landslides. Large land use changes without paying attention to the preservation of natural resources and environmental functions will cause land degradation which can lead to erosion, sedimentation, flooding, and landslides in the watershed ecosystem. Maryati (2013) states that land capability assessment is a process of evaluating land potential based on its ability to be used sustainably. According to Costa et al. (2019),

Table 3 - Water needs of the community around HLSW

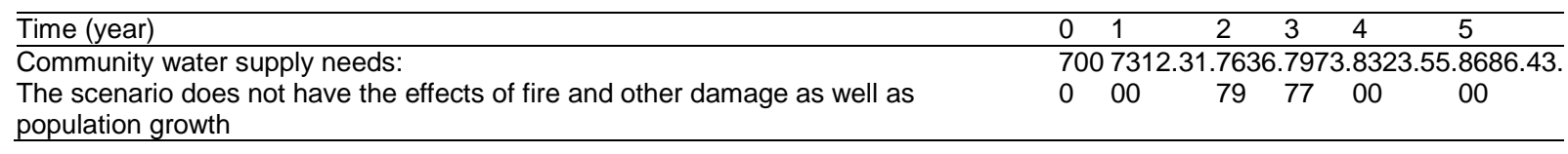

Population is one of the determining factors for the development of an area. The population development of Batu City from year to year is always increasing, this will have an impact on the influence of air resources, both now and in the future in an effort to meet the needs of clean water (Mahzum, 2014).

The graph of the pattern of community water demand which has increased every year can be seen in the graph of the increase in water demand each year. However, the need for water is limited by the carrying capacity of the environment so that at the limit of 65,000 people the graph experiences a fixed value, so that up to 100 years the need for water for services is a maximum of 65,000 people, can be seen in Figure 6.

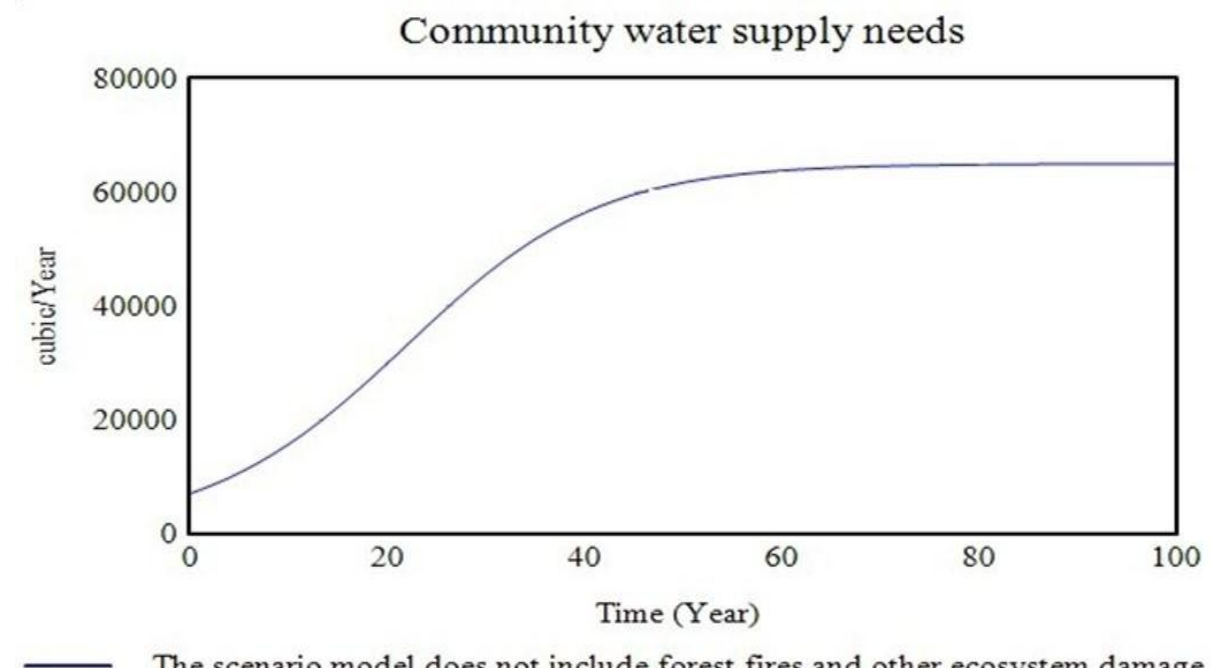

Figure 6 - Water needs of the community around HLSW

A scenario simulation without the effects of fire and other damage to the Sungai Wain Protected Forest ecosystem for water availability in the Sungai Wain Protection Forest with an initial volume of 5,506,420 $\mathrm{m} 3$ per year, serving the water needs of PT. Pertamina, the community around the Sungai Wain Protection Forest and the fire department, the maximum volume of water available in a scenario without the effects of fire and the impact of ecosystem damage in the 25th year is $800,000,000,000 \mathrm{~m}^{3}$ can be seen in Figure 7. 
Table 4 - Water availability in the HLSW ecosystem

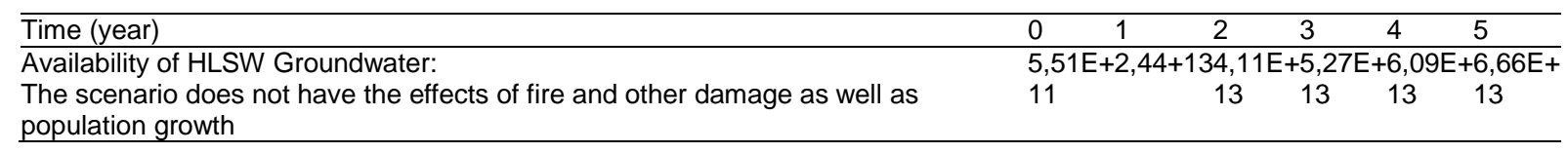

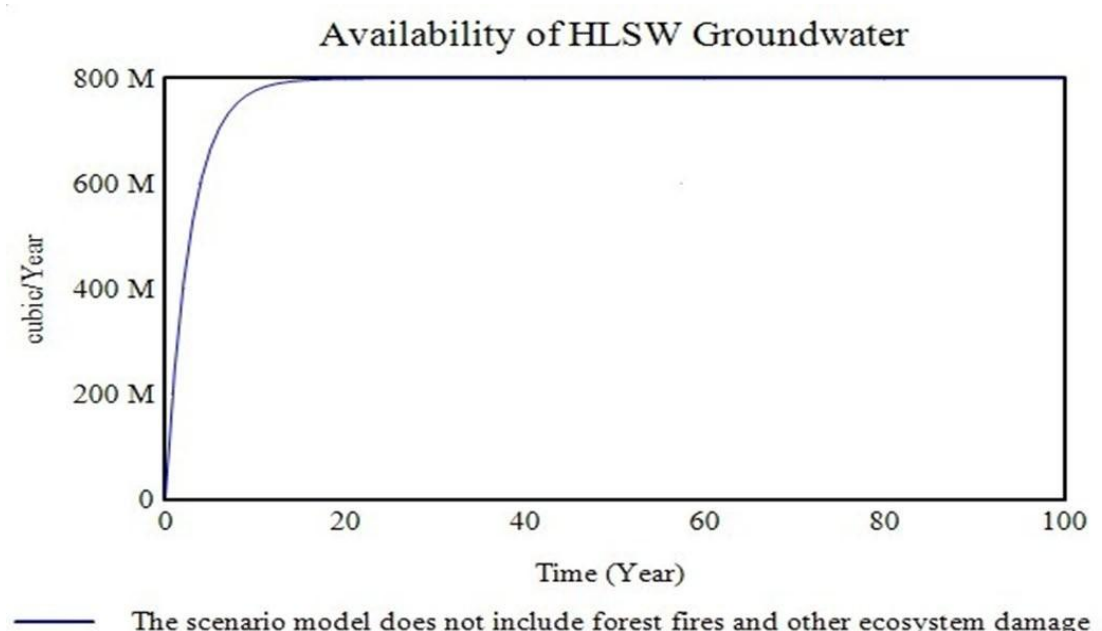

Figure 7 - Graph of water availability in HLSW

The level of water availability in the Wain River protected forest is influenced by the level of rainfall, the area of the Sungai Wain protected forest ecosystem and the level of the water runoff coefficient. If the ecosystem is maintained and there are no disturbances and threats of fire and other damage, then the level of water availability will be maintained. The graph towards the 100 years not finished mark. Although influenced by the level of need for Pertamina, the community and firefighters.

The impact of forest fires, from field research results in several numerical ratings of the total amount of fuel available for burning; and the Fire Weather Index (FWI), a numerical rating of fire intensity used as a general indicator of fire hazard. The components of the FWI system are calculated using daily temperature, relative humidity, wind speed, and 24 hour rainfall data collected at 1200 Local Standard Time. A fire weather station that supplies this data must meet standard criteria, as described by Turner and Lawson (1978).

The Canadian Forest Fire Behavior Prediction (FBP) System. FBP is a system that takes into account the variation in fire behavior of various types of fuel at several slope conditions which are quantitatively and descriptively based on the FWI conditions as input. The potential for fire activity (Forestry Canada Fire Danger Group 1992), and the effects of fires (de Groot et al. 2003) and are often applied in this way. predictive for preparing for serious fire problems (de Groot 1989). They have been used to estimate fire emissions (Taylor and Armitage 1993; Amiro et al. 2001) and can therefore be easily adjusted to predict smoke and haze.

In this scenario the FWI system model has been used in various applications in many other countries including the United States (for example, Brenner et al. 1997), New Zealand (National Rural Fire Authority 1993), Russia (Stocks et al. 1998), Fiji (Alexander 1989)), Mexico (Lee et al. 2002), and European countries (San-Miguel-Ayanz et al. 2003). The FWI system was used as the basis for developing the Southeast Asia FDRS which would serve as an early warning system for serious haze and fire problems.

In relation to water availability, it is closely related to the impact of forest fires, in the HLSW, so that the Drought Code (DC) index factors are a numerical ranking of the water content in the organic layer $10-20 \mathrm{~cm}$ below the ground surface, DC used as an indicator of the potential for drought and the potential for haze to occur. DC has an open scale, but scores in North America rarely go up to 800 (McAlpine 1991). High DC values indicate drier conditions in the deep organic layer including peat, and the potential for internal combustion, burning fires substantially increases when DC exceeds about 300 (de Groot 1988). 
In the scenario of changes in water availability behavior, the impact of changes originating from forest fires in HLSW and its surroundings, is influenced by the average fire index level such as in location one, with the index value of FFMC 73.7, DMC 10.1, DC 164, 76, ISI 1,6, BUI 17,2, FWI 2,403. Location two, with the index value of FFMC 82.3, DMC 50, DC 453.3, ISI 4.8, BUI 77.1, FWI

16.023. Location three, with an index value of FFMC 71.7, DMC 11, DC 116.3, ISI 1.8, BUI 17.3, FWI 2.67. Location four, with the FFMC index value 83.5, DMC 26.3, DC 247.5, ISI 3.8, BUI 41.3, FWI 9.358. Location five, with the index value of FFMC 55.3, DMC 5.2, DC 359.6, ISI 0.5, BUI 9.9, FWI 0.4.

In the Amazon forest, the effects of forest conversion from fire or cropland indicate severe changes in the hydrological cycle such as variability of groundwater storage and the ability to extract water from soil depth (Hodnett et al. 1995; Grip et al. 2004). The most important change in hydrological flow as a result of forest conversion is the change in the amount of water intercepted and evaporated into the atmosphere from surface vegetation (Dietz et al. 2006). Limited information is available for changes in vegetation structure caused by logging practices and forest fires or forest degradation. The water balance on the earth's surface can be disturbed due to forest degradation and conversion, especially in the division of rainfall into heavy rains, trunk flow, and intercepted by tree canopy or trunk (Sahin and Hall 1996). Generally, runoff and outflow increase when forests are cleared or degraded (Sahin and Hall 1996; Piao et al. 2006).

A scenario simulation of the impact of fire and other damage to the Sungai Wain Protected Forest ecosystem for Pertamina's initial water needs with an initial volume of $5,256,000 \mathrm{~m}^{3}$ per year, with an annual demand scenario of 5 percent. The existence of fires and other forest function damage does not affect the rate of demand for PT. Pertamina regarding the availability of HLSW, this is because the company PT. Pertamina is still below the minimum threshold for water production in HLSW. Damage rate of 20 percent, behavior model for the needs of PT. Pertamina, does not affect the water availability system in HLSW, the graph does not decrease and does not increase, starting to operate until the passage of time remains the same, the simulation can be seen in Figure 8, the rate of increase every year shows an increase.

Table 5 - Table of water requirements of PT. Pertamina with the consequences of fires and other ecosystem damage and without the consequences of fire and other ecosystem damage

\begin{tabular}{|c|c|c|c|c|c|c|}
\hline Time (year) & 0 & 1 & 2 & 3 & 4 & 5 \\
\hline Pertamina's water supply needs: & \multicolumn{6}{|c|}{$5,26 \mathrm{E}+5,52 \mathrm{E}+5,79 \mathrm{E}+6,08 \mathrm{E}+6,39 \mathrm{E}+6,71 \mathrm{E}+$} \\
\hline Scenario of the effects of fire and other damage and population growth & 0,9 & 10 & 11 & 11 & 10 & 11 \\
\hline Pertamina's water supply needs: & \multicolumn{6}{|c|}{$5,26 \mathrm{E}+5,52 \mathrm{E}+5,79 \mathrm{E}+6,08 \mathrm{E}+6,39 \mathrm{E}+6,71 \mathrm{E}+$} \\
\hline $\begin{array}{l}\text { The scenario does not have the effects of fire and other damage as well as } \\
\text { population }\end{array}$ & 0,9 & 10 & 11 & 11 & 10 & 11 \\
\hline
\end{tabular}

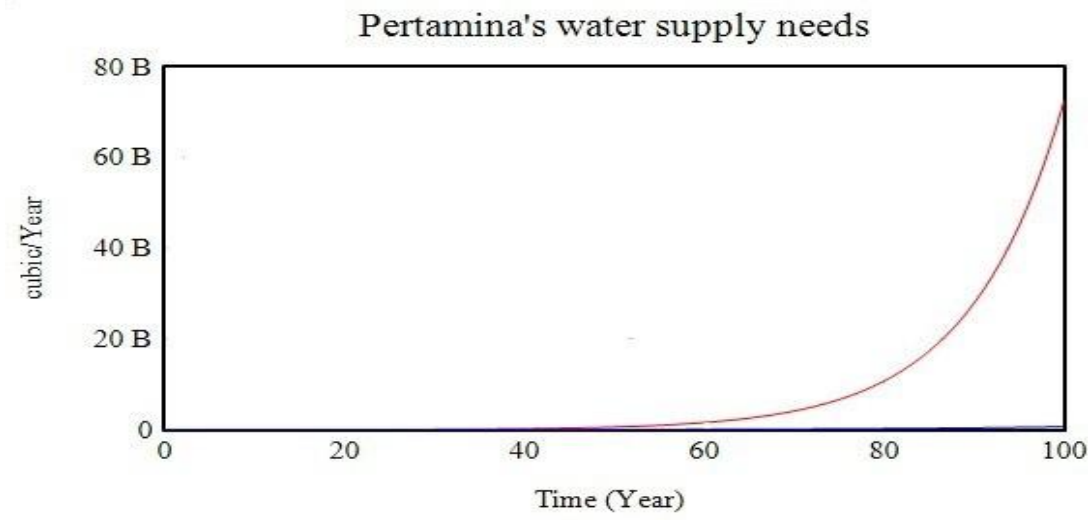

- The scenario model does not include forest fires and other ecosystem damage Scenario models of forest fires and other ecosystem damage

Figure 8 - Comparative graph between the effects of fire and other ecosystem damage without the effects of fire and other ecosystem damage 
If this scenario applies, the water demand model of PT. Pertamina can be seen as shown in Figure 8. Graphic behavior shows that in the next 5 years, the availability of water for the company can still be fulfilled by the amount of water needs of $67,100,000 \mathrm{~m}^{3}$ per year and this will increase every year. The environmental carrying capacity limit of water availability is $850,000,000 \mathrm{~m}^{3}$ and it is estimated that this need will occur in the eighteenth year, so companies need to find new methods to obtain additional water in the future.

Pertamina's water needs both during fires and ecosystem damage have no effect on the behavior of water availability, so that the graph increases all the time, is not exposed to fires and other ecosystems, this is influenced by the water availability limit which is getting higher in the value of the rate of fire and ecosystem damage. Other for that the system continues to run as long as it does not exceed the regulatory factor of water availability in Sungai Wain Protected Forest.

Simulation of the impact of fire and other damage to the Sungai Wain Protected Forest ecosystem for the initial need for firefighting water with an initial volume of 5,549.2 m3per year, with a scenario of water demand per year is 5 percent, and the environmental damage factor is 20 percent. The behavior of the model shows that the fire effect does not affect the water availability system in HLSW, this shows that the water demand capacity level of firefighting is still below the maximum limit of water availability in HLSW, this behavior is the same as the behavior simulation of the company PT. Pertamina, can be seen in Figure 9.

The level of demand for firefighting water shows an increase every year, this is due to the influence of increasing human behavior and their needs, so that the impact of fire disasters occurs all the time, so the graph increases every time. Graph due to the influence of fire and other forest damage, the system does not affect the water supply to each location of water needs

Table 6 - Value of fire extinguishing water needs along with the effects of fire and other damage and the absence of fire effects on the Sungai Wain Protection Forest (HLSW) ecosystem

\begin{tabular}{|c|c|c|c|c|c|c|}
\hline Time (year) & 0 & 1 & 2 & 3 & 4 & 5 \\
\hline Forest fire control model in the protected forest: & \multicolumn{6}{|c|}{ 5549.02.5826.6117.6423.6745.09.7082.34. } \\
\hline Scenarios of the effects of fire and other damage and popular & 00 & 66 & 99 & 89 & 00 & 00 \\
\hline Forest fire control model in the protected forest: & \multicolumn{6}{|c|}{ 5549.02.5826.6117.6423.6745.09.7082.34. } \\
\hline The scenario does not have the effects of fire and other damage & 00 & 66 & 99 & 89 & 00 & 00 \\
\hline
\end{tabular}

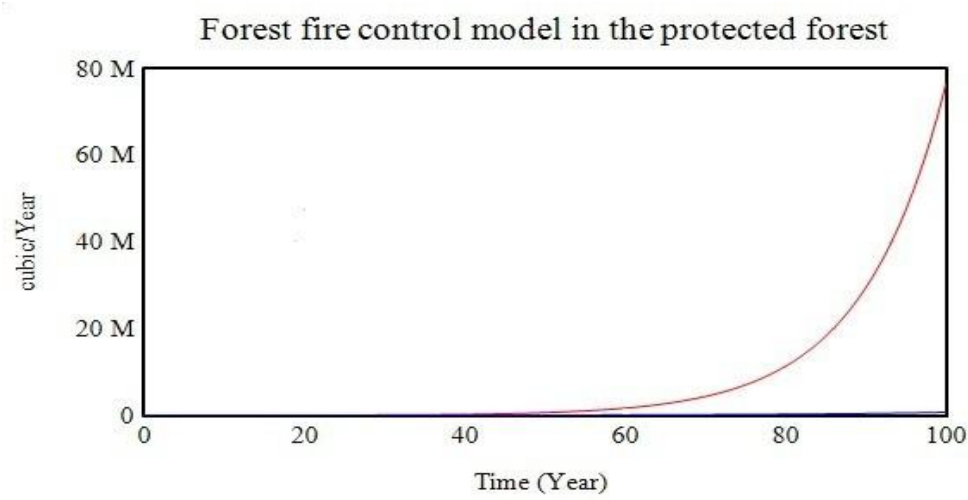

- The scenario model does not include forest fires and other ecosystem damage Scenario models of forest fires and other ecosystem damage

Figure 9 - Graph of extinguishing water demand Community water supply needs

Simulation of a scenario model without the effects of fire and other damage with the effects of fire and other damage to the community around the Sungai Wain Protection Forest with an initial volume of 7,000 m3 per year, population growth is the impact of the determination of Penajam Kabupaten and Kabupaten Kutai Kartanegara, East Kalimantan as the capital of the Unitary State. Republic of Indonesia. The result of this decision is that Balikpapan City is the city closest to the two regencies, so that the population growth has increased by 20 percent from the previous one, but is limited by the carrying capacity of the 
environment of 65,000 people, resulting in an increase. does not exceed the maximum carrying capacity of the environment, if it has reached the carrying capacity of the environment, then the maximum need that can be served is the maximum environmental carrying capacity.

The difference in the graph between before the fire and after the fire. Whether running in the same system, graphical behavior without the effects of fire and other ecosystem damage, tends to be earlier than the maximum water requirement, when compared to without the effects of fire, can still increase at a better rate.

Table 7 - Value of water needs of communities around HLSW, fire and other ecosystem damage and no fires and other ecosystem damage

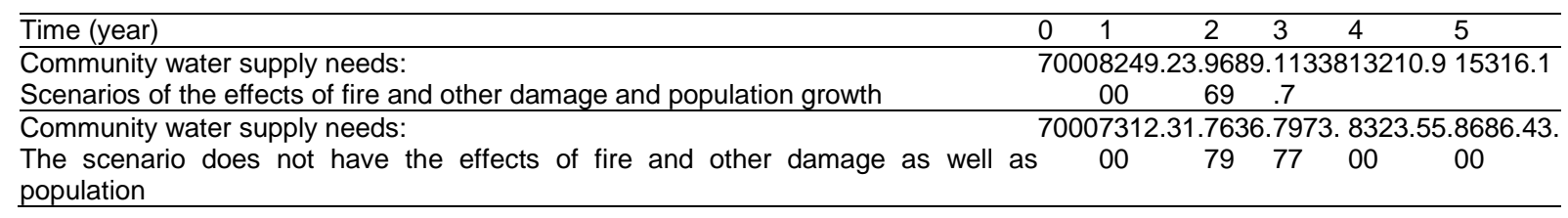

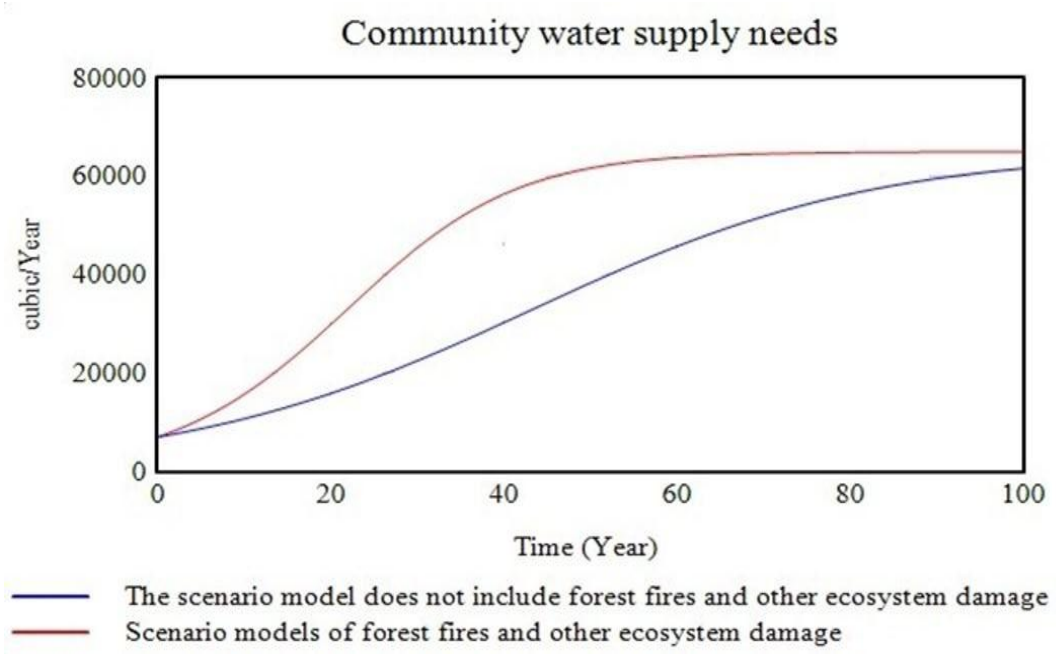

Figure $10-$ Graph of the effects of fire and other ecosystem damage and without the effects of fire and other ecosystems.

There is a change in model behavior, before fires and other ecosystem damage, water demand tends to be linear, but after fires and other ecosystem damage at a rate of 20 percent there is an interaction between population growth and a decrease in the function of forests to absorb or store water.

Simulation of a scenario model without the effects of fire and other damage with the effects of fire and other damage to water availability in the HLSW ecosystem with an initial volume of 5,506,420 m3 per year, an increase in population of 20 percent, designation of Penajam District and Kutai Kartanegara Regency of East Kalimantan as the Capital of the Unitary State of the Republic Indonesia and the impact of fires and other ecosystem damage, will affect the availability of raw water from the HLSW ecosystem, the graphic behavior of the two is different, especially the behavior of water availability. When there is no fire, water availability is abundant, but after fires and other ecosystem damage, water availability decreases, can be seen in Figure 11.

The graph of groundwater availability in Sungai Wain Protection Forest after being influenced by the behavioral pressures of the level of fire and forest destruction and population growth in the area around the Sungai Wain protected forest has a major influence on the initial demand graph. There is a difference in the graph when there is no fire load $t$ and ecosystem damage, so the graph functions normally, but when there is fire pressure and ecosystem damage, the behavior of the graph changes the volume of water availability in the river protection forest. 
Table 8 - Value of water availability in HLSW when fire and other ecosystem damage occurs and without fire and other ecosystem damage

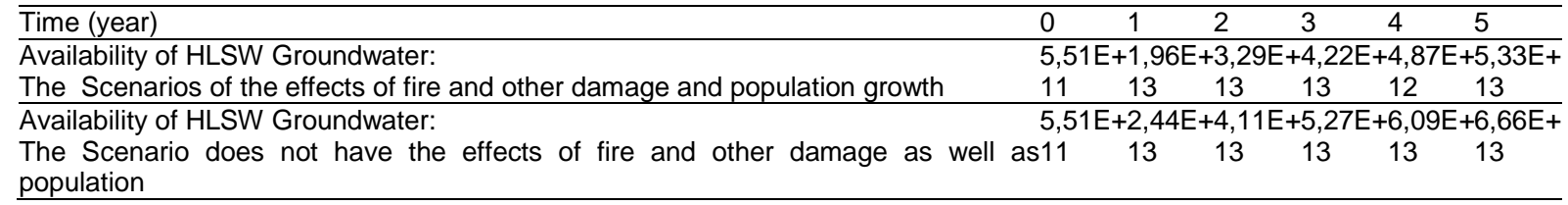

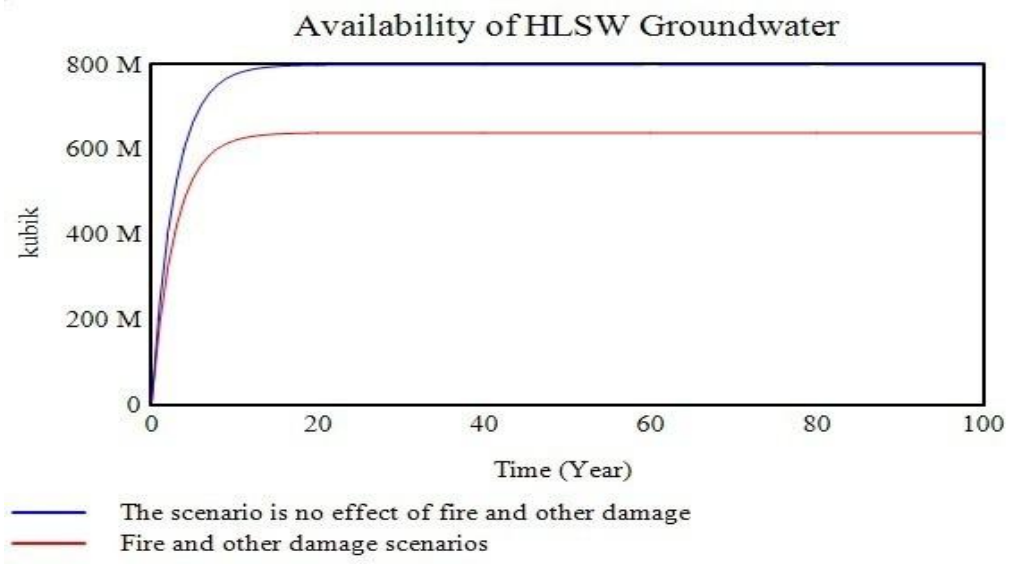

Figure 11 - Water availability in HLSW occurs when fire and other ecosystem damage occurs and without fire and other ecosystem damage

Looking at the data in Table 8 shows that there are differences in model behavior, scenarios without the effects of fire and other ecosystem damage, water availability is able to survive in providing water services to PT. Pertamina, the community around HLSW and firefighters for 25 years. After the effects of fires and other ecosystem damage, service capacity decreased from 25 years of service to 18 years of service. The influence of negative behavior on the system comes from the high level of water demand from the community and the presence of fires and other ecosystem damage, so that both are able to have a negative effect on the system ecosystem.

The conclusion of the dynamic model of the water availability system in the protected forest of the Wain River is the water supply for PT. Pertamina, the communities around the Sungai Wain protected forest location and the need for firefighters, do not reduce the availability of water in the Sungai Wain protected forest, unless it exceeds the annual demand coefficient. The simulation of the effect of fire and damage to the protected forest ecosystem of the Wain river is an extreme FWI value of 22.3 and a population increase of 20 percent, the increase in population is estimated to be influenced by the determination of Penajam and Kutai Kartanegara Districts as the capitals of the Unitary State. The Republic of Indonesia, these two cities are directly adjacent to the research area. Fires and population growth greatly influence the behavior of the scenario models for the effects of fire and other ecosystem damage.

The condition of the Sungai Wain protected forest area with an area of 11,245 hectares, there are several types of vegetation in the form of forest land cover which will affect the influence of groundwater and surface water. Forests function as water regulators, namely by holding rain to reduce surface erosion and infiltrate the ground, then releasing it regularly into various air currents above the surface and below the surface, so that its distribution is better for various purposes outside the forest. Himself, (Darusman, 1993). Forests and rain will produce water runoff through rivers and an infiltration process in forest areas, leading to reservoirs and rivers.

According to Bishop (1999), forest area values are calculated by determining the market price of forest products produced. Based on the market price of a forest product, the value of a forest area with a certain function will be obtained. Thus, the calculation of the value of the forest area as a water provider can be calculated by calculating the amount of 
water utilized multiplied by the price or value of water according to the standard.

The calculation of price determination is carried out by taking into account the average air price set by PDAM Kota Balikpapan in 2018 of IDR 5,771.00 per cubic (m3) for general consumers and IDR 22,022.00 per cubic (m3) for large industries. In 2018, the calculation of the price which is used as the basis for calculating the economic assessment of the Sungai Wain Protected Area is the average price between the community price and the price of large industries is Rp. $13,896.00$ per cubic (m3). Based on the simulation results of the water calculation model in the Sungai Wain protected forest, the net amount of water that can be utilized is $2,910,100,000 \mathrm{m3}$, the economic value of the water in the Sungai Wain protected forest is Rp. 40,440,204,650,000.00 for 2019.

For the economic value of the community in utilizing protected forest water from the Wain River is IDR 2,233,221,183.00 per year, the price of water based on the price of drinking water companies for households in Balikpapan City is 5,771 per m3 and the level of community demand per year is 10,591,200 m3. The economic value of water used by the company PT. Pertamina is IDR $121,535,000,000.00$, the industry standard price is IDR 22,022.00 per $\mathrm{m} 3$ from the Balikpapan City drinking water company and the level of need for the company PT. Pertamina is $5,518,800 \mathrm{~m} 3$ per year. It can be seen in Table 9 , an analysis of the economic value of water in HLSW for a 50 year scenario.

Table 9 - The results of the analysis of the economic value of water in the Sungai Wain protection forest, the water economy for the community and PT. Pertamina

\begin{tabular}{cccc}
\hline Time (Year) & $\begin{array}{c}\text { HLSW air ecosystem runoff } \\
\text { (Rupiah) }\end{array}$ & Water needs of the population (Rupiah) & $\begin{array}{c}\text { Water needs of PT. Pertamina } \\
\text { (Rupiah) }\end{array}$ \\
\hline 2019 & $1,47 \mathrm{E}+11$ & 2.233 .221 .183 & $1,22 \mathrm{E}+11$ \\
2024 & $3,11 \mathrm{E}+13$ & 5.539 .384 .207 & $2,16 \mathrm{E}+11$ \\
2029 & $8,53 \mathrm{E}+13$ & 13.419 .174 .414 & $3,84 \mathrm{E}+11$ \\
2034 & $1,58 \mathrm{E}+14$ & $3,14 \mathrm{E}+10$ & $6,83 \mathrm{E}+11$ \\
2039 & $2,66 \mathrm{E}+14$ & $7,05 \mathrm{E}+10$ & $1,21 \mathrm{E}+12$ \\
2044 & $4,35 \mathrm{E}+14$ & $1,50 \mathrm{E}+11$ & $2,16 \mathrm{E}+12$ \\
2049 & $7,04 \mathrm{E}+14$ & $3,00 \mathrm{E}+11$ & $3,84 \mathrm{E}+12$ \\
2054 & $1,14 \mathrm{E}+15$ & $5,67 \mathrm{E}+11$ & $6,85 \mathrm{E}+12$ \\
2059 & $1,83 \mathrm{E}+15$ & $1,02 \mathrm{E}+12$ & $1,21 \mathrm{E}+13$ \\
2069 & $2,95 \mathrm{E}+15$ & $1,86 \mathrm{E}+12$ & $2,38 \mathrm{E}+13$ \\
\hline
\end{tabular}

Vegetative soil and air conservation can be carried out through the management of plants in the form of trees or shrubs, both annual plants and plants and grasses. This technology is often combined with soil and water conservation measures in a management manner (Sinukaban, 2003). Vegetative soil management can guarantee the sustainability of soil and air because it has the following properties: (1) additional soil structure through the root system by increasing soil granulation, (2) land cover by litter and canopy reduces evaporation, (3) in addition to increasing microorganism activity which increases the increase in soil porosity, thereby increasing the amount of infiltration and preventing erosion.

Vegetative soil and air conservation can be implemented through the management of plants in the form of trees or shrubs, both perennials and perennials and grasses. These technologies are often combined with management measures for soil and water conservation (Sinukaban, 2003). Vegetative soil management can guarantee soil and air sustainability because it has the following characteristics: (1) maintaining the stability of the soil structure through the root system by increasing soil granulation, (2) land cover by litter and the canopy to reduce evaporation, (3) in addition to it can increase the activity of microorganisms which increase soil porosity, thereby increasing the amount of infiltration and preventing erosion.

The total value of the economic benefits of HLSW, is the value of the benefits of water for 2019, utilization of community air and utilization of water from PT. Pertamina, is Rp. 123,768,221,183, - year (2019), according to Rujehan (2010), the value of the economic benefits of HLSW obtained from biological and ecological elements as support for community household income is an average of Rp. 28,367,327, - per household per year (in 2008), for the 2019 value using the future value formula, the interest rate is $10 \%$ per year (Future Value) $=$ IDR $80,935,295.00$. The total value of economic benefits from HLSW is IDR $123,849,156,478$. 


\section{AKNOWLEDGEMENTS}

During research and research preparation, many volunteers helped even though it was difficult to find data due to the conditions of the COVID 19 outbreak, but God helped a lot in completing this research and preparation.

\section{REFERENCES}

1. Alexander ME. 1989. Fiji adopts Canadian system of fire danger rating. Int For Fire News II (1):3.

2. Ardhana IPG. 2012. Plant Ecology. Udayana University Press, Bali. [Indonesian].

3. Arrijani. 2006. Correlation between Trees Architecture Model with Stem flow, Canopy Interception, Infiltration, Surface Flow, and Erosion. [Dissertation]. Bogor Agricultural University, Bogor. [Indonesian].

4. Astiani D, Mujiman, Rafiastanto A. 2017. Forest type diversity on carbon stocks: Cases of recent land cover conditions of tropical lowland, swamp, and peatland forests in West Kalimantan, Indonesia. Biodiversitas 18 (1): 137-144.

5. A review of sustainable forestry management as a tool for meeting conservation goals. Retrieved 23 September 2020, from https://www. stateoftheapes.com reports sustainableforestry-management-ape-conservation.

6. Badri M, Lubis DP, Susanto D, Suharjito D. 2018. Early warning communication system for forest and land fire prevention in Riau Province. Journal of Communication Research and Development.

7. Bishop R. 1999. Kaupapa Maori research: An indigenous approach to creating knowledge. In Robertson, N. (Ed). Maori and psychology: Research and practice. Proceedings of a symposium sponsored by the Maori \& Psychology Research Unit, Department of Psychology, University of Waikato, Hamilton, Thursday 26th August 1999 (pp.1-6). Hamilton, New Zealand: Māori and Psychology Research Unit, University of Waikato.

8. BNPB, PB. 2013. Guidelines for post-disaster needs assessment. Jakarta: National Disaster Management Agency.

9. Brenner J, Arvanitis LG, Brackett DP, Lee BS, Carr RJ, Suddaby RM. 1997. Integrating GIS, mesoscale fire weather prediction, smoke plume dispersion modeling, and the internet for enhanced open burning authorizations and wildfire response in Florida. Proceedings of the GIS User's Conference, http://aris.sfrc.ufl.edu/Laboratories/GIS/presentations/612p.htm.

10. Brown LE, K Johnson, SM Palmer, KL Aspray and J Holden. 2013. River ecosystem response to prescribed vegetation burn-ing on blanket peatland. PLoS ONE 8:e81023.

11. Collins RD. 2012. Forest fire management in Portugal: developing system insights through models of social and physical dynamics. MSc Thesis. Massachusetts Institute of Technology, Cambridge, MA, USA. https://dspace.mit.edu/handle/1721.1/72651.

12. Costa RCA, Pereira GT, Pissarra TCT, Siqueira DS, Fernandes LFS, Vasconcelos V, Fernandes LA, Pacheco FAL. 2019. Land capability of multiple-landform watersheds with environmental land use conflicts. Land Use Pol 81: 689-704.

13. Darusman D. 1993. Nilai Ekonomi Air Untuk Pertanian dan Rumah Tangga: Studi Kasus Di Sekitar Taman Nasional Gunung Gede Pangrango. Disampaikan pada Simposium Nasional Permasalahan Air di Indonesia di ITB, 28 - 29 Juli 1993.

14. Daye DD, Healey JR. 2015. Global Ecology and Conservation 3.349-358.

15. De Grip A, Van Loo J, \& Sanders J. 2004. The industry employability index: Taking account of supply and demand characteristics. Int'l Lab. Rev., 143, 211.

16. de Groot WJ. 1988. Interpreting the canadian forest Fire Weather Index System (FWI). In: Hirsch KG (ed.), Proceedings of the scientific and technical seminar on the fourth central regional fire weather committee. Can for Serv, Edmonton, Alberta, Study NOR36-03-1, File Rep 3, pp. 3-14.

17. de Groot WJ. 1989a. Development of the saskatchewan fire preparedness system. In: 
Hirsch KG (ed.), Proceedings of the scientific and technical seminar on the sixth central regional fire weather committee, Can for Serv, Edmonton, Alberta, Study NOR-36-03-1, File Rep 5, pp. 23- 49.

18. de Groot WJ. 1989b. Technology transfer in Saskatchewan: operational use of Canada's forest fire hazard rating system. In: Maclver DC, Auld H (eds.) Proceedings of the 10th conference on fires and forest meteorology, Atmos Environ Serv, Downsview, Ontario, pp. 327-332.

19. de Groot WJ, Bothwell PM, Carlsson DH, Logan KA (2003) Simulating the effects of future fire regimes on boreal forests of Western Canada. J Vegetarian Sci 14: 355-364.

20. de Groot WJ, Field RD. 2004. Guide to the Southeast Asian fire hazard rating system. Report to the Canadian agency for international development. Canadian forest service, Edmonton, Alberta Unpubl File Report.

21. de Groot WJ Wardati, Wang Y. 2005. Calibrating a fine fuel moisture code for potential ignition of grass in Sumatra, Indonesia. Int J Wildland Fire 14: 161-168.

22. de Paula JS, Lisboa CM, de Castro Meneghim M, Pereira AC,Ambrosano GM, Mialhe FL. 2015. School performance and oralhealth conditions: analysis of the impact mediated by socio- economic factors. Int J Paediatr Dent.

23. Dietz C, Swinkels S, van Daalen E, van Engeland H, Buitelaar JK. 2006. Screening for autistic spectrum disorderin children aged 14-15 months II: population screening with theEarly Screening of Autistic Traits Questionnaire (ESAT).Journal of Autism and Developmental Disorders, 36(6), 713-722.

24. Fauzi A, \& Fariantika A. 2018. Courses perceived difficult by undergraduate students majoring in biology. Biosfer: Jurnal Pendidikan Biologi, 11(2), 78-89.

25. Forestry Canada Fire Danger Group. 1992. Development and structure of a Canadian forest fire behavior prediction system. Ottawa, ON, To Can Rep. ST-X-3.

26. Harjianto M, Sinukaban N, Tarigan, S.D, Haridjaja O. 2016. Land Capability Evaluation for Land Use Recommendation in Lawo Watershed Jurnal Penelitian Kehutanan Wallacea 5: 1-11. . [Indonesian].

27. Hodnett MG, Da Silva LP, Da Rocha HR, \& Senna RC. 1995. Seasonal soil water storage changes beneath central Amazonian rainforest and pasture. Journal of hydrology, 170(1-4), 233-254.

28. Krebs CJ. 2009. Ecology: The Experimental Analysis of Distribution and Abundance. 6th ed. Benjamin Cummings, San Francisco.

29. Lawler JJ, Lewis DJ, Nelson E, Plantinga AJ, Polasky S, Withey JC, Helmers DP, Martinuzzi S, Pennington D, Radeloff VC. 2014. Projected land-use change impacts on ecosystem services in the United States PNAS, 111 (20)pp. 7492-7497.

30. Lee BS, Alexander ME, Hawkes BC, Lynham TJ, Stocks BJ, Englefield P. 2002. Information systems in support of wildland fire management decision making in Canada. Computers and Electronics in Agriculture 37:185-198.

31. Levia DF, Frost EE. 2006. Variability of throughfall volume and solute inputs in wooded ecosystems. Prog Phys Geogr 30:605-632.https://doi.org/10.1177/0309133306071145.

32. Mahzum MM, \& Mardyanto MA. 2014. Analisis Ketersediaan Sumber Daya Air Dan Upaya Konservasi Sub Das Brantas Hulu Wilayah Kota Batu. In Seminar Nasional Pascasarjana XIV- ITS, Surabaya.

33. Marsono Dj. 2008. The requirement use of the ecosystem knowledge in Land and Forest Management. Speech on the 45th Anniversary of Faculty of Forestry, Yogyakarta, November 7, 2008. [Indonesian].

34. Maryati. 2013. Land Capability Evaluation of Reclamation Area in Indonesia Coal Mining Using LCLP Software. Procedia Earth Planet Sci 6: 465-473.

35. McAlpine RS. 1991. Seasonal trends in the Drought Code component of the Canadian Forest Fire Weather Index System, Petawawa, ON, For Can, Inf Rep PI-X-97.

36. Mueller-Dombois D. and Ellenberg H. 1974 Aims and Methods of Vegetation Ecology. John Wiley and Sons, New York, $547 \mathrm{p}$.

37. Muhammad Badri, Djuara $P$ Lubis et al. 2018. Risk communication in prevention of forest and land fires in Riau Province. Bogor Agricultural Institute. 
38. Muhammadi. 2001. Analisis Sistem Dinamis - Lingkungan Hidup, Sosial, Ekonomi, Manajemen. UMJ Press, Jakarta.

39. Odum EP. 1998. Dasar-dasar Ekologi. Diterjemahkan dari Fundamental of. Ecology oleh T. Samingan. Gadjah Mada University Press. Yogyakarta.

40. Paimin (et.al). 2012. Sistem Perencanaan Pengelolaan Daerah Aliran Sungai, Pusat Penelitian dan Pengembangan Konservasi dan Rehabilitasi, Bogor.

41. Parejiya NB, Detroja SS, Panchal NS. 2013. Vegetation analysis at Bandiyabedi Forest in Surendranagar District of Gujarat State of India. Intl J Life Sci Biotechnol Pharm Res 2 (2): $241-247$.

42. Piao S L, Fang JY, Zhou LM, Ciais $P$ \& Zhu B. 2006. Variations in satellitederivedphenologyin China's temperate vegetation. Glob. Change Biol. 12, 672-685.

43. Postel SL. and Thompson BH Jr. 2005. 'Watershed protection: Capturing the benefits of nature's water supply services', Natural Resources Form, 29: pp.98-108.

44. Presidential Decree of the Republic of Indonesia Number 32 of 1990 concerning management of protected forest areas, Jakarta.

45. Profauna, 2016, This is the Intimate Relationship Between Forests and Water Availability

46. Purnomo H, Shantiko B, Gunawan H, Gaveau D, Sitorus S, Salim MA, Achdiawan R. 2015. The political economy of forest and land fires in Riau: An Analytical Approach [Paper]. Prevent Forest and Land Fires.

47. Ramadhan R, Widiatmaka, Sudadi U. 2016. Land use change and spatial utilization in landslide vulnerable regions of Banjarnegara Regency, Central Java. Jurnal Pengelolaan Sumberdaya Alam dan Lingkungan 6: 159-167. [Indonesian].

48. Rujehan. 2010. Pengelolaan Kawasan Hutan Lindung Sungai Wain (HLSW) Kalimantan Timur. Disertasi Fakultas Pertanian Universitas Brawijaya, Malang. pp. 261.

49. Regulation of the Head of the National Disaster Management Agency number 2 of 2012

50. Regulation of the Minister of Environment and Forestry of the Republic of Indonesia Number P.32 / Menlhk / Setjen / Kum. 1/3/2016 concerning Forest and Land Fire Control.

51. Sahin V, \& Hall MJ. 1996. The effects of afforestation and deforestation on water yields. Journal of hydrology, 178(1-4), 293-309.

52. San-Miguel-Ayanz J, Barbosa P, Liberta G, Schmuck G, Schulte E, Bucella P. 2003. The European Forest Fire Information System: European Strategy towards Forest Fire Management. Proceedings of the 3rd International Wildland Fire Conference, Sydney, Australia. Washington, D C, U S Dep Interior, Bur Land Management CD-ROM.

53. Susanto. 2012. Pengendalian Terpadu Oryctes rhinoceros di Perkebunan Kelapa sawit. PPKS Medan.

54. Stocks BJ, Fosberg MA, Lynham TJ, Mearns L, Wotton BM, Yang Q, Jin J-Z, Lawrence K, Hartley GR, Mason JA, McKenney DW. 1998. Climate change and forest fire potential in Russian and Canadian boreal forests. Clim Change 38:1-13.

55. Taylor SW, Armitage OB. 1993. Prescribed Fire Emissions Predictor - Version 1.00. User guide, Documentation and Evaluation, Victoria, BC, For Can, File Rep (unpubl.)

56. Turner J.A., and Lawson BD. 1978. Weather in the Canadian forest fire danger rating system: A user guide to national standards and practices. Canadian Forest Service publication. BC-X177, May, 1978. pp. 40.

57. Triwanto J. 2012. Forest Land and Watershed Conservation.

58. Walpole RE. 1982. Introduction of Statistics. 3rd Edition, Macmillan Publishing Company, Inc., New York, 247-304.

59. Wang C, Chuan YZ, Zhong LX, Yang W, Huanhua P. 2013. Effect of vegetation on soil water retention and storage in a semi arid Alpine forest catchment. J Arid Land 5 (2): 207-219.

60. Yan Y, Xu X, Xin X, Yang G, Wang X, Yan R, Chen B. 2011. Effect of Vegetation Coverage on Aeolian Dust Accumulation in Semiarid Steppe of Northern China. Catena 87: 351-356.

61. Zheng MG, Cai Q, Chen H. 2007. Effect of vegetation on runoff-sediment yield relationship at different spatial scales in Hilly Areas of the Loess Plateau, North China. Acta Ecol Sin 27 (9): 3572-3581. 